\title{
Determinants of Behavioral Intentions to Use Sharia Financial Technology
}

\author{
Dani Setiawan $^{1^{*}}$, Darwanto ${ }^{2}$, Edy Yusuf Agung Gunanto ${ }^{3}$ \\ 1, 2, 3Universitas Diponegoro, Indonesia \\ E-mail: ${ }^{1}$ danise.undip@gmail.com, ${ }^{2}$ darwantomsiugm@gmail.com, ${ }^{3}$ edy.yusuf.ag@gmail.com \\ ") Corresponding author
}

JEL Classification:

$\mathrm{D} 83$

D91

G2

$\mathrm{Z1}$

Received: May 15, 2021

Revised: June 30, 2021

Accepted: July 14, 2021

\begin{abstract}
The growth of sharia fintech is not proportional to the majority of the Muslim population. There are only a few studies that discuss the behavioral intentions of consumers who use sharia fintech. This study aims to identify the factors influencing Muslim's behavioral intentions in using sharia fintech. This study conducted 400 respondents in four types of sharia fintech (digital payment, lending, crowdfunding, and risk and management). This study uses a structural Equation Modeling - Partial Least Square (SEM-PLS) approach. Variable Planned behavior (PB), Acceptance Model (AM), Use of Technology (UT), Digital Literacy (DL), and Sharia Financial Literacy (SFL) have significant positive effects on Behavior Intention (BI). This study provides recommendations to improve the distribution of internet access infrastructure and the right curriculum in increasing digital literacy, Islamic finance literacy, and also more accessible fintech services.
\end{abstract}

\section{Keywords:}

acceptance model, behavior intention, digital literacy, sharia fintech, sharia financial literacy.

How to Cite:

Setiawan, D., Darwanto., \& Gunanto, E. Y. A. (2021). Determinants of Behavioral Intentions to Use Sharia Financial Technology. Signifikan: Jurnal Ilmu Ekonomi, 10(2), 325-342. https://doi.org/10.15408/sjie.v10i2.21451. 


\section{Introduction}

The digital economy in Indonesia has great potential to develop rapidly. The Oxford Economics Report (2016) stated that it is projected to contribute an additional 640 million USD to Indonesia's Gross Domestic Product (GDP) for every one percent increase in internet penetration. Google \& TEMASEK (2018) explained that one of the critical factors in the development of the digital economy is a large number of internet users in Indonesia. In 2020, Indonesia experienced a significant increase in internet penetration over the past decade. In 2019-2020 internet penetration as measured by the percentage of internet users from the total population increased by $14.90 \%$, or $62.60 \%$ of the total population. It was contrasting to the year 2018-2019, which only increased by $7.90 \%$ or $47.69 \%$ of the total population of Indonesia.

Fintech has changed the way consumers and investors conduct financial transactions (Huei et al., 2018). Based on the KPMG report (2020), global investment in fintech companies reached USD 4,256,202 million in 2018. It is projected that in 2022 global transactions will reach USD 7,971,957 million with a predicted growth of $17 \%$. Jung (2016) explained that the fintech industry segment refers to the payment business, loan facilities, crowdfunding, financial advisors, and insurance. Based on the AFTECH report (2020), in 2020, the fintech industry players increased to 362 members from the previous year in 2019, which was only 275 members. Bank Indonesia (2020) reported that in 2020 there were 353 million electronic money instruments with total transactions reaching IDR 16.1 trillion. The development of sharia fintech lending is still far behind compared to conventional fintech lending. In 2020, the percentage of sharia fintech lending was only $7.2 \%$ of the total fintech lending in Indonesia. Fintech crowdfunding in ZISWAF's management in Indonesia has excellent potential with $87.21 \%$ of the Muslim population. The fintech mix will make it easier for the Muslim community to fulfill its religious obligations.

The demand for digital and cashless transactions worldwide affects the attitudes of fintech users and their adoption, which has undergone drastic changes (Alalwan et al., 2017; Leong et al., 2013). Researchers have extensively explored various aspects of fintech payment services which are considered as a universal payment solution for consumers as well as merchants, and influence behavioral intentions as well as technology use (Alalwan et al., 2017; Ramos de Luna et al., 2019; Slade et al., 2015). Consumers prefer technology that provides fast, convenient, and valuable services on a single platform. Fintech services demonstrate advanced multipurpose techniques that include such features (Abhishek \& Hemchand, 2016; Schierz et al., 2010; Shin, 2009; Thakur \& Srivastava, 2014).

Low awareness of technology, privacy norms, resistance, innovation, infrastructure support, benefits, and uses are the main obstacles to shifting to digital things. Therefore, people only focus on the few advantages they will receive if they use fintech (Oliveira et al., 2016). The sophistication of technology can enhance cost efficiency and support modernization and innovation (Mukhtar \& Ahmad, 2010). Personal data security issues become another concern for consumers when making payments through fintech (Hossain 
et al., 2019; Apanasevic et al., 2016). The long-term use of fintech is defenseless and dubious (Ryu, 2018). There is a need for research that proposes critical factors that influence people's intention to keep using digital financial services (Rana et al., 2015).

This study uses the theory of Planned Behavior (PB) developed by Ajzen (1985) with indicators of Attitude Toward Behavior (ATB), Perceived Behavior Control (PBC), and Subjective Norm (SN), which have been proven to explain Behavioral Intentions (BI) using sharia fintech (Solomon et al., 2013; Haider et al., 2016; Glavee-Geo et al., 2017; Darmansyah et al., 2020). The Technology Acceptance Models (AM) (TAM) 2 and (TAM) 3 proposed by Davis (1989) have an Image (IM) indicator construction; Job Relevance (JR); Output Quality (OQ); and Result Demonstration (RD). Meanwhile, TAM 3 indicators are Perception of External Control (PEC); Computer Anxiety (CA); Computer Playfulness (CP); Perceived Enjoyment (PE) has been tested in various countries in estimating the behavioral intention to use sharia fintech (Zhang et al., 2018; Akhtar et al., 2019; Thaker et al., 2019; Darmansyah et al., 2020). The Use of Technology (UT) refers to theory (UTAUT) 2 by Venkatesh \& Davis (2000) consisting of indicators Social Influence (SI1), Price Value (PV1), Habit (HB1) has been tested empirically in explaining behavioral intentions using fintech sharia (Baptista \& Oliveira, 2015; Raza et al., 2018; Mohd Thas Thaker et al., 2020; Darmansyah et al., 2020). Researchers have widely used these theories to explore the intentions of fintech users.

Technology adoption cannot be separated from the role of digital literacy. Digital literacy is the influence of an individual in making the ability to continuously improve, understand, and utilize emerging innovations to make intelligent decisions about the adoption of a new one (Jeremy et al., 1996). Belshaw (2011) stated that one's literacy influences decisions in using and supporting technology. In this case, Muslims' understanding of digital literacy in fintech services is one example of decisions used to adopt technology (Affan, 2019). In addition, the literacy factor can be applied by the community to understand something that has been digitized (Coutinho, 2007). Behavioral intentions and consumer trust are also influenced by the intensity of someone using the service (Stewart et al., 2018).

This study contributes to the literature on Muslims' behavioral intentions to use sharia fintech. To the best of our knowledge, previous studies primarily focused on the customer preferences in adopting mobile banking. Few studies have identified consumer intentions to use sharia fintech. The literature on Islamic banking and finance, according to Narayan \& Phan (2019), is mainly focused on the Islamic bank performance (44 percent), equities market performance ( 24 percent), market interaction (15 percent), and asset pricing (15 percent) ( 7 percent). Even though FinTech has garnered the attention of stakeholders, its long-term usage remains vulnerable and dubious (Ryu, 2018). Being skeptical of significant and unexpected risks is a barrier to realizing sharia fintech's full potential. This study aims to fill the gap by analyzing the difference between the exogenous (independent) latent variable and the endogenous (dependent) latent variable on the four types of Sharia fintech in Indonesia. This study estimates PB, AM, and UT to explain 
BI on the use of sharia fintech. In addition, the novelty in this study is estimating the digital literacy (DL) and sharia financial literacy (SFL) factors in the sharia fintech adoption model. This study provides an excellent opportunity for future researchers to develop theoretical studies of digital literacy, technology acceptance models, and sharia financial literacy closely related to the intention to use sharia fintech in Indonesia.

Figure 1 The Conceptual Framework of the study

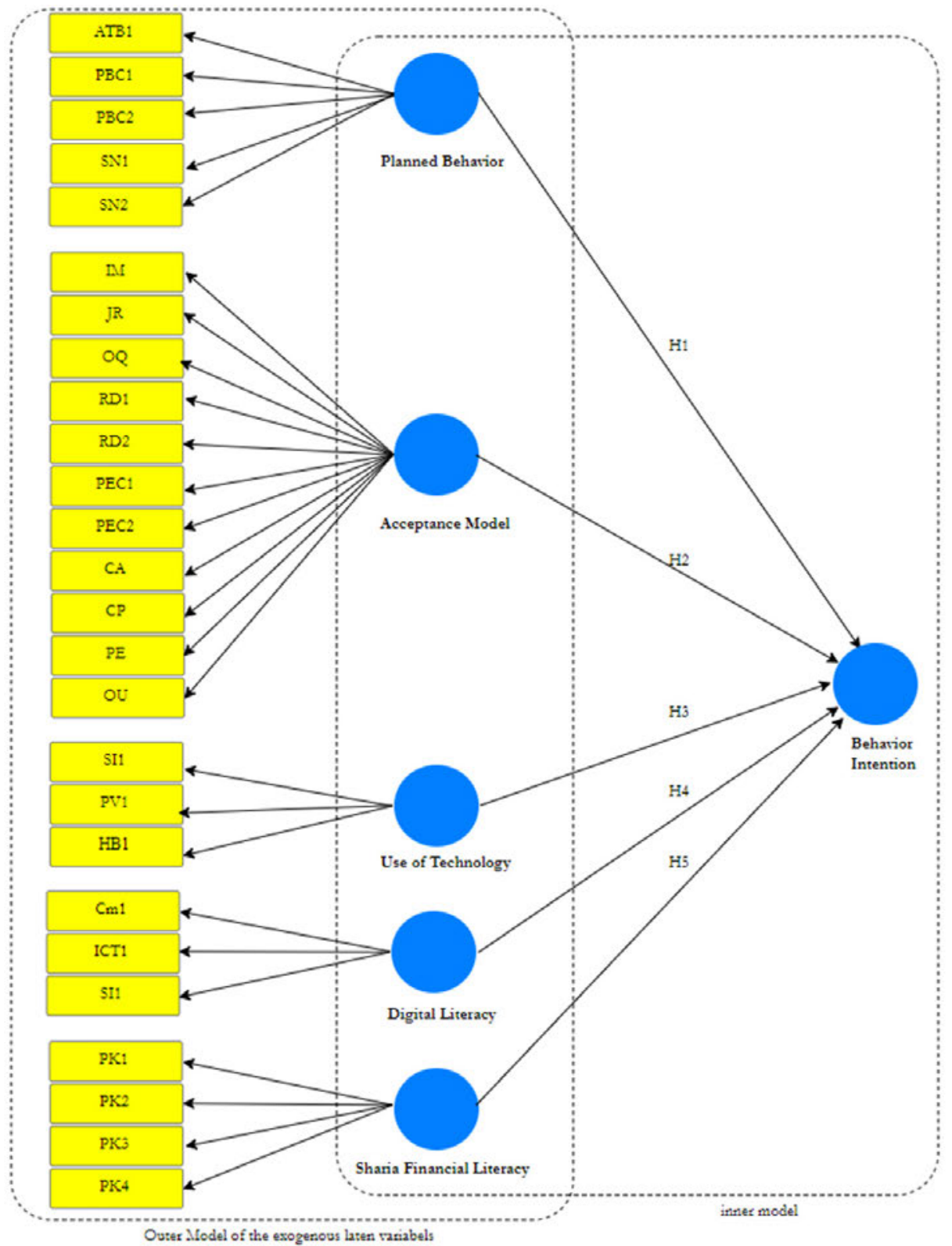

\section{Method}

This study uses the Structural Equation Modeling technique with Partial Least Square (SEM-PLS), a component-based predictive model with a variance-based or component-based approach. The stages of SEM-PLS analysis according to Ghozali \& 
Latan (2015): 1) determining the concept of the model; 2) determining the algorithm analysis method; 3) determining the resampling method; 4) determining the path diagram; 5) evaluating the model (evaluating the outer and inner models). This study analyzes four types of sharia fintech in Indonesia: fintech payment, fintech lending, fintech social crowdfunding, fintech risk, and management. The number of samples used was 400 respondents who were obtained by distributing online questionnaires.

Figure 1 shows a framework model used by this study. This study uses five variables: $\mathrm{PB}$ using one item of ATB1 indicator, two PBC items, and two SN items. This study adopts 11 indicators of a combination of TAM 2 and TAM 3 on the AM variable. The TAM 2 indicators used to explain AM are IM1 one item, JR one item; OQ of one item; and RD of two items. Meanwhile, the TAM 3 indicator is represented by two items of PEC; one item of CA1, one item of CP; one item of PE1. The UT variable in this study uses three indicators: one item of SI, one item of PV, and one item of HB. The indicators used in the DL latent variables are one item of Functional Skill and Beyond (ICT1), one item of Communication ( $\mathrm{Cm} 1)$, one item of E-safety (Sv1). The SFL variable consists of four indicators, namely PK1, PK2, PK3, and PK4.

\section{Result and Discussion}

\section{Characteristics of respondents}

Table 1 demonstrates a summary of respondents' characteristics from four types of sharia fintech. It concludes that the majority of sharia fintech service users are male. Sharia, fintech lending users, have a significant gap between male (78\%) and female users (22\%). The education level of sharia fintech payment users is dominated by high school graduates (58\%), fintech lending (59\%), fintech crowdfunding (56\%), and sharia fintech risk and management (67\%). There are zero master graduates found in fintech lending and sharia risk and management. Overall, four types of sharia fintech users remain at the high school education level.

Moreover, Table 1 presents the type of work of sharia fintech users. Fintech payments are dominated by students (39\%). The majority of fintech lending users (91\%) are entrepreneurs or self-employed. Fintech crowdfunding is dominated by users with the type of company workers (37\%). And the rest is financial risk and managing users dominated by students (70\%) from higher education levels as investment trends arise among millennials. The majority of sharia fintech users are between 17-25 years old. However, sharia fintech lending is dominated by users aged 26-35 years (70\%).

The income and expenses of sharia fintech users are spread into six levels. The majority of payment users have an income between IDR 1-3 million (65\%) with an expenditure of less than IDR 2 million in one month (54\%). On the other hand, fintech lending (77\%) and crowdfunding (52\%) are dominated by income levels of IDR 4-5 million, with the level of expenditure of IDR 2-4 million. Risk and management fintech users with an income of IDR 1-3 million (87\%) with expenses of IDR $>2$ million (71\%). 


\section{SEM-PLS Model Evaluation}

The evaluation of the model is carried out through an assessment of the model's size by testing the validity and reliability of latent constructs, then evaluating the structural model and testing the significance of the influence between constructs and variables, Ghozali \& Latan (2015). The SEM-PLS analysis goes through two stages of evaluation:

a. Evaluation of the Measurement Model (Outer Model)

b. Evaluation of the Structural Model (Inner Model)

Table 1 The Descriptive statistics of users: four types of sharia fintech service

\begin{tabular}{|c|c|c|c|c|c|c|c|c|}
\hline \multirow{3}{*}{ characteristic } & \multirow{2}{*}{\multicolumn{2}{|c|}{$\begin{array}{c}\begin{array}{c}\text { Sharia Fintech } \\
\text { Payment }\end{array} \\
(n=100)\end{array}$}} & \multirow{2}{*}{\multicolumn{2}{|c|}{$\begin{array}{c}\begin{array}{c}\text { Sharia Fintech } \\
\text { Lending }\end{array} \\
(n=100)\end{array}$}} & \multirow{2}{*}{\multicolumn{2}{|c|}{$\begin{array}{l}\text { Fintech Crowdfunding } \\
\qquad(n=100)\end{array}$}} & \multirow{2}{*}{\multicolumn{2}{|c|}{$\begin{array}{c}\begin{array}{c}\text { Fintech Risk And Sharia } \\
\text { Management }\end{array} \\
(n=100)\end{array}$}} \\
\hline & & & & & & & & \\
\hline & Sub-totals & $\%$ of $n$ & Sub-totals & $\%$ of $n$ & Sub-totals & $\%$ of $n$ & Sub-totals & $\%$ of $n$ \\
\hline \multicolumn{9}{|l|}{ gender } \\
\hline man & 59 & 59 & 78 & 78 & 51 & 51 & 56 & 56 \\
\hline woman & 41 & 41 & 22 & 22 & 49 & 49 & 44 & 44 \\
\hline \multicolumn{9}{|l|}{ Education Background } \\
\hline Senior High School & 58 & 58 & 59 & 59 & 56 & 56 & 67 & 67 \\
\hline Academy (D1/D2/D3) & 7 & 7 & 18 & 18 & - & - & 5 & 5 \\
\hline D4/S1/S.Tr & 29 & 29 & 23 & 23 & 32 & 32 & 28 & 28 \\
\hline S2/S3 & 6 & 6 & & & 12 & 12 & & \\
\hline \multicolumn{9}{|l|}{ work } \\
\hline Student / Student & 39 & 39 & - & - & 29 & 29 & 70 & 70 \\
\hline employee & 22 & 22 & - & - & 37 & 37 & 19 & 19 \\
\hline Civil Servants & 16 & 16 & - & - & 7 & 7 & - & - \\
\hline Self employed & 18 & 18 & 91 & 91 & 20 & 20 & 9 & 9 \\
\hline Other & 5 & 5 & 9 & 9 & 7 & 7 & 2 & 2 \\
\hline \multicolumn{9}{|l|}{ age } \\
\hline $17-25$ & 66 & 66 & 27 & 27 & 55 & 55 & 87 & 87 \\
\hline $26-35$ & 24 & 24 & 70 & 70 & 42 & 42 & 11 & 11 \\
\hline $36-45$ & 6 & 6 & 3 & 3 & 3 & 3 & 2 & 2 \\
\hline $46-55$ & 4 & 4 & & & - & - & & \\
\hline \multicolumn{9}{|l|}{ income } \\
\hline 1 - 3 million & 65 & 65 & 19 & 19 & 42 & 42 & 82 & 82 \\
\hline 4 - 5 million & 14 & 14 & 77 & 77 & 52 & 52 & 15 & 15 \\
\hline 6 - 10 million & 21 & 21 & 4 & 4 & 6 & 6 & 3 & 3 \\
\hline 11 - 15 million & - & - & - & - & - & - & - & - \\
\hline \multicolumn{9}{|l|}{ expense } \\
\hline$<2$ million & 54 & 54 & & & 35 & 35 & 71 & 71 \\
\hline 2 - 4 million & 25 & 25 & 96 & 96 & 63 & 63 & 28 & 28 \\
\hline 5 - 9 million & 21 & 21 & 4 & 4 & 2 & 2 & 1 & 1 \\
\hline
\end{tabular}




\section{Measurement Model Evaluation (Outer Model)}

The outer model or known as the outer relation/measurement model explains the relationship between each indicator block and its latent variables. The measurement model is carried out by testing the convergent validity, discriminant validity test, and composite reliability test. Recommendations for convergent and discriminant validity tests if the value of factor loading (FL) (> 0.7) and the value of Average Variance Extracted (AVE) is (> 0.5) (Ghozali \& Latan, 2015). Composite reliability which measures a construction can be evaluated with Cronbach's alpha (CA) and Composite reliability $(\geq 0.7)$ (Ghozali \& Latan, 2015). The results of the measurement model are shown in Table 2.

Table 2. shows that the values (FL) (>0.7); (AVE) (>0.5); (CA) and CR $(\geq 0.7)$ in each construction of the latent variable are higher than the recommended level, so it can be indicated that the model construction has met the convergent validity test, discriminant validity test, and composite reliability test.

\section{Structural Model Evaluation}

The evaluation of the inner model is a structural model test to determine the direct or indirect effect between the research variables. The stages of evaluating the inner model are analyzing the R-square value, the Q-Square value, and the path diagram.

Table 2 R-square and Q-Square Test

\begin{tabular}{lll}
\hline R Square & R Square Adjusted & Q Square \\
\hline 0.912 & 0.911 & 0.750 \\
\hline
\end{tabular}

Based on the R-Square Adjusted test in table 3 shows that the Behavior Intention variable in testing on sharia fintech has a value of 0.911 . The effect of exogenous variables on endogenous variables is 0.911 or $91.1 \%$. The value of Q-Square $(\mathrm{Q} 2>0)$ in Islamic finance is 0.750 , simultaneously the value of the diversity of this research data can be explained by the structural model equal to $75 \%$ so, it can be concluded that the model has predictive relevance.

Table 3 Path Analysis

\begin{tabular}{cccccccc}
\hline $\begin{array}{c}\text { Research } \\
\text { Hypothesis }\end{array}$ & & Path & & $\begin{array}{c}\text { Path } \\
\text { Coefficient }\end{array}$ & t-statistics & $p$-values & information \\
\hline $\mathrm{H} 1$ & $\mathrm{~Pb}$ & $\rightarrow$ & $\mathrm{Bi}$ & 2.173 & 21.127 & 0.000 & Significant \\
$\mathrm{H} 2$ & $\mathrm{Am}$ & $\rightarrow$ & $\mathrm{Bi}$ & 0.234 & 5.864 & 0.000 & Significant \\
$\mathrm{H} 3$ & $\mathrm{Ut}$ & $\rightarrow$ & $\mathrm{Bi}$ & 0.133 & 4.086 & 0.000 & Significant \\
$\mathrm{H} 4$ & $\mathrm{DI}$ & $\rightarrow$ & $\mathrm{Bi}$ & 0.732 & 10.174 & 0.000 & Significant \\
$\mathrm{H} 5$ & $\mathrm{SFL}$ & $\rightarrow$ & $\mathrm{Bi}$ & 0.224 & 6.304 & 0.000 & Significant \\
\hline
\end{tabular}


Based on bootstrap analysis output, all factors have a positive influence on behavior intention. planned behavior $(\beta=2,173)=0.05(\rho=0.000<0.05)$; acceptance model $(\beta$ $=0.234)=0.05(\rho=0.000<0.05)$; use of technology $(\beta=0.133)=0.05(\rho=0.000$ $<0.05)$; digital literacy $(\mathrm{DL})(\beta=0.732)=0.05(\rho=0.000<0.05)$; sharia financial literacy $(\mathrm{SFL})(\beta=0.224)=0.05(\rho=0.000<0.05)$. H1, H2, H3, H4 and H5 were supported in this study (See Figure 2).

Planned behavior (PB) has a positive influence on behavior intention (BI) (H1) as much as 2.173. This research reinforces Solomon et al's research, (2013) stating that $\mathrm{SN}$ is a social norm that influences one's perception of the adoption of technological innovation. The consumption pattern or behavior of Muslims' society is influenced by the prevailing norms in Islam. The study is also in line with Haider et al. (2016) finding that social norms have a significant impact on the formation of behavioral intentions to adopt mobile banking. The findings in this study support the results of Glavee-Geo et al., (2017) stated that factors influence the intention of individuals in Pakistan to adopt mobile banking. The positive and significant influence of Planned Behavior (PB) on Behavior Intention (BI) to use sharia fintech also strengthens the findings of Darmansyah et al. (2020).

Figure 2 SEM-PLS Inner Model

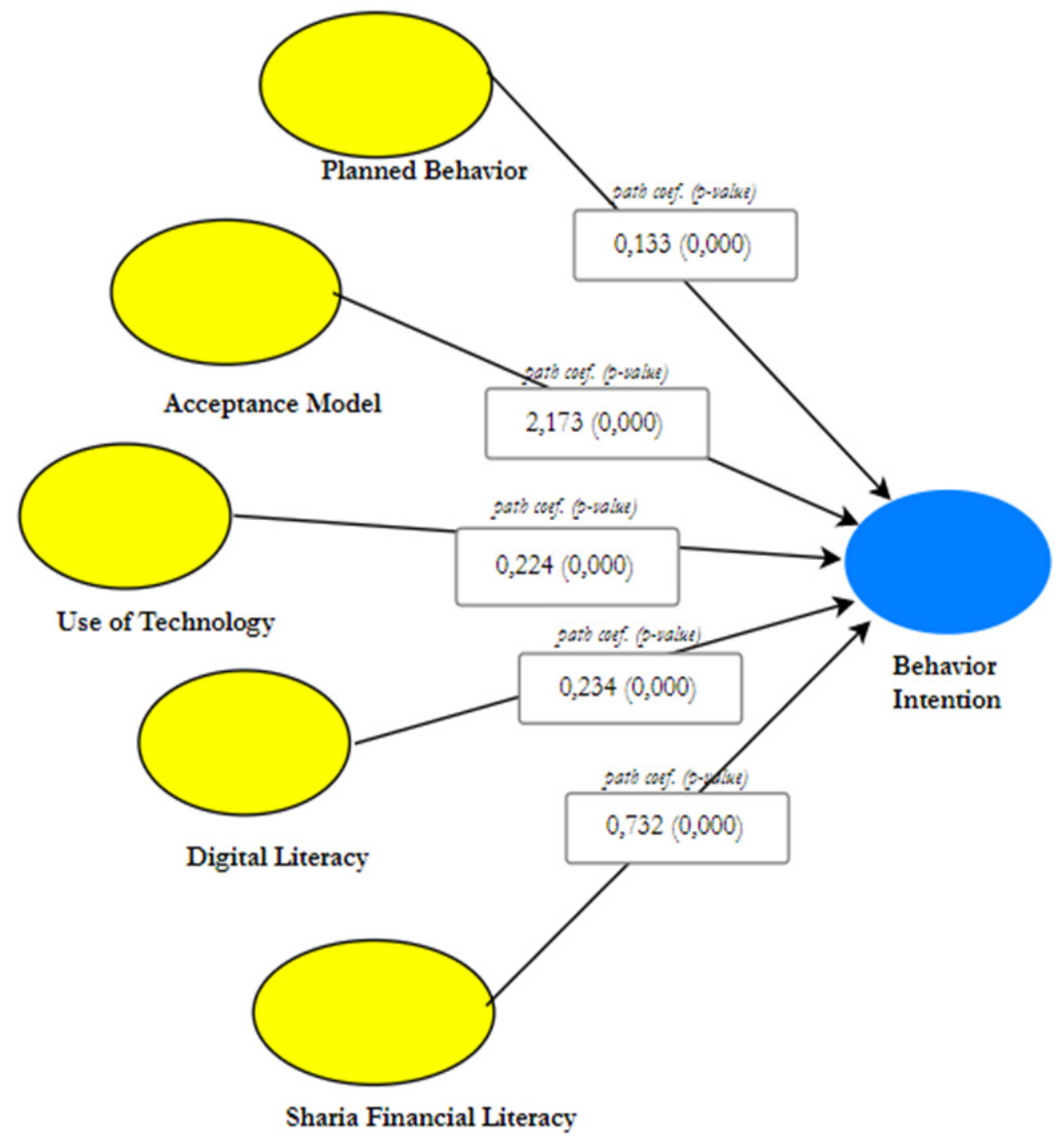


Table 2 Output of the SEM-PLS Outer Model

\begin{tabular}{|c|c|c|c|c|c|}
\hline Items & & FI & $\mathrm{Cr}$ & Ave & $\mathrm{Ca}$ \\
\hline Planned Behavior (PB) & & & 0.959 & 0,683 & 0,953 \\
\hline Indicators & Questionnaire Statement & & & & \\
\hline ATB1 & $\begin{array}{l}\text { Using sharia fintech will provide benefits } \\
\text { in my life }\end{array}$ & 0.824 & & & \\
\hline PBC1 & $\begin{array}{l}\text { I have the resources and knowledge to } \\
\text { use sharia fintech }\end{array}$ & 0.753 & & & \\
\hline PBC2 & I can use sharia fintech & 0.858 & & & \\
\hline SN1 & $\begin{array}{l}\text { People around me believe that using } \\
\text { sharia fintech is useful }\end{array}$ & 0.796 & & & \\
\hline SN2 & $\begin{array}{l}\text { The popular people I know are sharia } \\
\text { fintech users }\end{array}$ & 0.9 & & & \\
\hline Acceptance Model (AM) & & & 0.907 & 0,830 & 0,796 \\
\hline IM1 & Using sharia fintech increases my prestige & 0.818 & & & \\
\hline JR1 & $\begin{array}{l}\text { Using sharia fintech helped me in various } \\
\text { transactions }\end{array}$ & 0.877 & & & \\
\hline OQ1 & $\begin{array}{l}\text { my performance is influenced by sharia } \\
\text { fintech }\end{array}$ & 0.908 & & & \\
\hline RD1 & $\begin{array}{l}\text { I can easily acquire the financial benefits } \\
\text { of sharia fintech services }\end{array}$ & 0.797 & & & \\
\hline RD2 & $\begin{array}{l}\text { I can easily obtain non-financial benefits } \\
\text { (time and energy), which I get from sharia } \\
\text { fintech services }\end{array}$ & 0.773 & & & \\
\hline PEC1 & $\begin{array}{l}\text { I have full access to the Sharia fintech } \\
\text { application used (account and password) }\end{array}$ & 0.897 & & & \\
\hline PEC2 & $\begin{array}{l}\text { Sharia fintech application is compatible } \\
\text { with the software (operating system) I use }\end{array}$ & 0.892 & & & \\
\hline CA1 & $\begin{array}{l}\text { I'm not worried about transaction failure if } \\
\text { I use the sharia fintech application }\end{array}$ & 0.917 & & & \\
\hline CP1 & $\begin{array}{l}\text { I carefully operate systems or technologies } \\
\text { in sharia fintech applications }\end{array}$ & 0.733 & & & \\
\hline PE1 & I think using sharia fintech is effective & 0.715 & & & \\
\hline OU1 & $\begin{array}{l}\text { I think sharia fintech is faster and cheaper } \\
\text { than other transaction methods (offline } \\
\text { transactions) }\end{array}$ & 0.727 & & & \\
\hline Use of Technology (UT) & & & 0.881 & 0,713 & 0,797 \\
\hline SI1 & $\begin{array}{l}\text { Most of the people around me use sharia } \\
\text { fintech applications. }\end{array}$ & 0.866 & & & \\
\hline PV1 & $\begin{array}{l}\text { Sharia fintech applications have an } \\
\text { affordable cost. }\end{array}$ & 0.84 & & & \\
\hline HB1 & $\begin{array}{l}\text { The use of sharia fintech applications has } \\
\text { become a habit for me. }\end{array}$ & 0.842 & & & \\
\hline
\end{tabular}




\begin{tabular}{|c|c|c|c|c|c|}
\hline Items & & $\mathrm{FI}$ & $\mathrm{Cr}$ & Ave & $\mathrm{Ca}$ \\
\hline Digital Literacy (DL) & & & 0.916 & 0,685 & 0,884 \\
\hline ICT1 & $\begin{array}{l}\text { I have the ability in the field of information } \\
\text { technology to operate a computer / } \\
\text { smartphone and the internet }\end{array}$ & 0.853 & & & \\
\hline Cm1 & $\begin{array}{l}\text { I can communicate through digital } \\
\text { technology media }\end{array}$ & 0.894 & & & \\
\hline Sv1 & $\begin{array}{l}\text { I can guarantee security when exploring } \\
\text { digital technology }\end{array}$ & 0.782 & & & \\
\hline $\begin{array}{l}\text { Sharia Financial Literacy } \\
\text { (SFL) }\end{array}$ & & & 0.961 & 0,861 & 0,946 \\
\hline PK1 & $\begin{array}{l}\text { I understand the basic knowledge of } \\
\text { Sharia finance }\end{array}$ & 0.946 & & & \\
\hline PK2 & $\begin{array}{l}\text { The working system of the sharia } \\
\text { economy uses the principle of profit- } \\
\text { sharing in a business cooperation }\end{array}$ & 0.911 & & & \\
\hline PK3 & $\begin{array}{l}\text { I know the products (savings, insurance, } \\
\text { and investments) in sharia digital finance }\end{array}$ & 0.947 & & & \\
\hline PK4 & $\begin{array}{l}\text { I know of financial transactions that } \\
\text { contain elements }\end{array}$ & 0.907 & & & \\
\hline Behavioral Intention (BI) & & & 0.886 & 0,721 & 0,808 \\
\hline BI1 & $\begin{array}{l}\text { I intend to use sharia fintech application in } \\
\text { the future }\end{array}$ & 0.92 & & & \\
\hline $\mathrm{BI} 2$ & $\begin{array}{l}\text { I will always try to use sharia fintech } \\
\text { applications in my daily life. }\end{array}$ & 0.902 & & & \\
\hline
\end{tabular}

The acceptance model (AM) had a positive influence on behavior intention (BI) (H2) of 0.234. This study supports Zhang et al. (2018) show that some TAM indicators are reflected by the emotional reaction of consumers to use financial technology applications. Acceptance Model (AM) has also been proven in the research of Thaker et al., (2019) which explored the factors that influence consumer decisions in using mobile banking in Malaysia. This study supports Akhtar et al. (2019) research on the effect of several TAM indicators on the adoption of mobile banking in Pakistan and China. This research also supports Zhang et al. (2018) which shows that some TAM indicators include Perceived Enjoyment (PE), which is reflected in the emotional customer reaction to using the application, significantly affects the attitude of customers which in turn affects the intention to adopt mobile banking. The positive and significant influence of the Acceptance Model (AM) on Behavior Intention (BI) on the use of sharia fintech in this study reinforces the findings of Darmansyah et al. (2020).

The Use of Technology (UT) has a positive effect on behavior intention (BI) (H3) of 0.133. The results of this hypothesis test support the research of Baptista \& Oliveira (2015) which uses UTAUT as a guiding framework for understanding behavioral intentions towards mobile banking adoption in Africa. The research of Raza et al., (2018) 
was also successfully supported in this study, where the habit indicator (HB) is a factor that affects the acceptance of Islamic mobile banking in Pakistan. The research of Mohd Thas Thaker et al., (2020) has confirmed that some representative components such as perceived values are important in adopting technology. In this study, the positive and significant effect of The Use of Technology (UT) on Behavior Intention (BI) on the use of Sharia fintech strengthens the findings of Darmansyah et al. (2020).

Digital literacy (DL) has a positive influence on behavior intention (H4) of 0.732 . This finding has been proven by Hargittai \& Hinnant (2008) and Howard et al. (2020) who explained that literacy is a strong predictor of the use of digital activities such as searching for information and online banking by individuals. Rodríguez-de-Dios et al., (2018) found that digital literacy can help consumers improve their ability to use digital financial services. Elhajjar \& Ouaida (2019) also strengthens this study by their findings that digital literacy significantly influences consumer attitudes in using digital banking services in Lebanon. Furthermore, the research of Nedungadi et al. (2020) stated that digital literacy is important so people can access financial services safely.

Sharia financial literacy (SFL) has a positive influence on behavior intention (H5) of 0.224 . This research supports research conducted by Morgan \& Long (2020) which stated that the correlation between financial literacy is very close to the awareness of almost all fintech products. Performance expectancy and financial literacy have a positive and significant impact on behavioral intentions to adopt fintech.

\section{Behavior Intention for Four Types of Sharia Fintech}

Data analysis in this study was carried out in two stages. The first stage to examine the overall research variables for Sharia fintech. The analysis is continued by comparing four competing models for sharia fintech types, they are sharia fintech payment, sharia fintech lending, fintech crowdfunding (donation-based), and sharia fintech risk and management. Figure 3 describes the analysis of the path diagram to compare four types of sharia fintech consisting of 1) sharia payment fintech; 2) sharia fintech lending; 3) fintech social crowdfunding; 4) sharia fintech risk and management.

The table 5 shows the evaluation of the path analysis comparison of four types of Sharia fintech. In the type of sharia fintech payment, all variables have a positive and significant influence on Behavior Intention. Planned behavior shows the value $(\beta=0.151)$ $(\rho=0.000<0.05 ;=0.05)$; Acceptance Model (AM $(\beta=2.705)(\rho=0.000<0.05 ;=$ $0.05)$; Use of Technology $(\beta=0.345)(\rho=0.000<0.05 ;=0.05)$; Digital Literacy $(\beta=$ $0.403)(\rho=0.000<0.05 ;=0.05)$; Sharia Financial Literacy $(\beta=0.981)(\rho=0.000<$ 0.05 ; = 0.05). Sharia fintech (Figure 3 ) has a positive and significant impact on (BI) in sharia fintech payments, sharia fintech lending, fintech crowdfunding (donation based) and has no effect on sharia fintech risk and management contrary to the research of Darmansyah et al. (2020) which found that the positive and significant influence of (PB) on (BI) only occurred in the type of sharia fintech payment.

In the type of sharia fintech lending, all variables have a positive and significant 
influence on (BI). In the type of Fintech Crowdfunding (donation-based), there is one variable that is not significant, namely the Use of Technology variable with coefficient value $(\beta=0.122)(\rho=0.095>0.05 ;=0.05)$. However, other variables have a positive and significant effect on Behavior Intention (BI). In sharia fintech Risk and Management there is also one variable that does not have a significant effect on (BI), namely the Planned behavior variable $(\beta=-0.089)(\rho=0.113<0.05 ;=0.05)$. However, other variables have a positive and significant effect.

Figure. 3 SEM-PLS results: four competing models of sharia fintech

\section{Sharia Fintech: Payment}

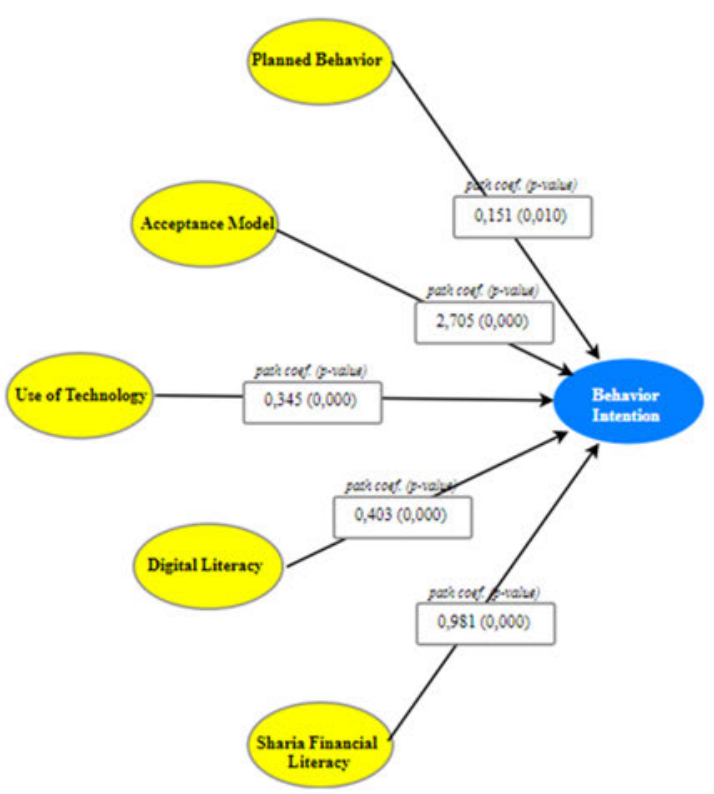

Sharia Fintech: Crowdfunding (Donation Based)

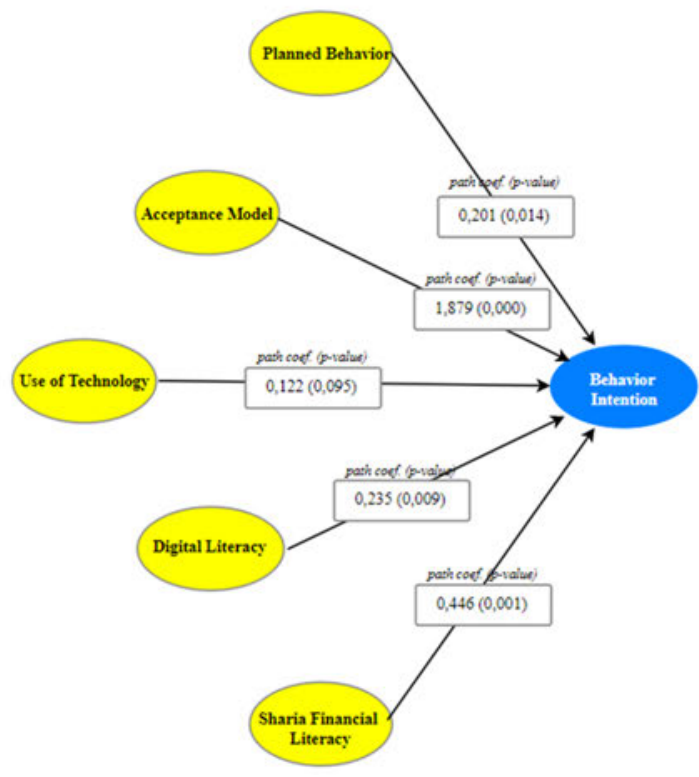

Sharia Fintech: Lending

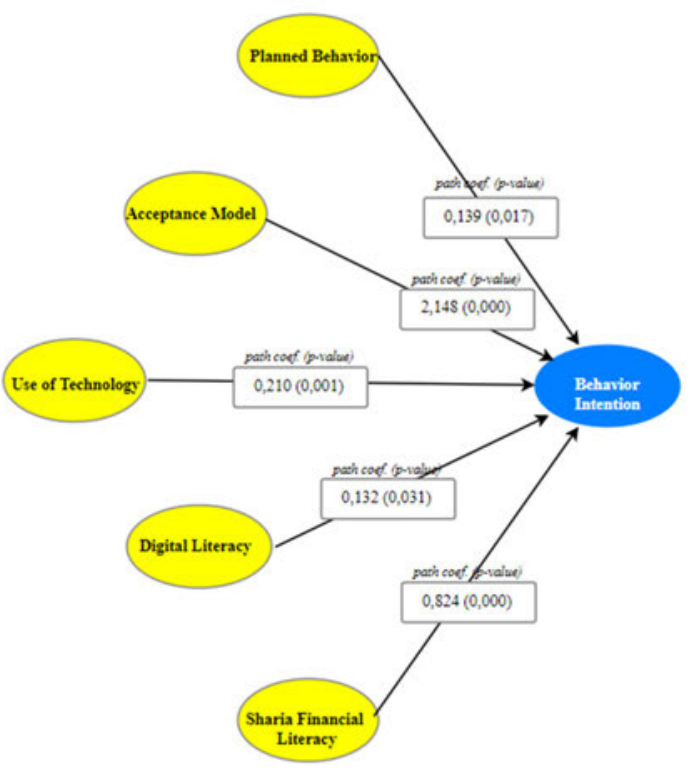

Sharia Fintech: Risk \& Management

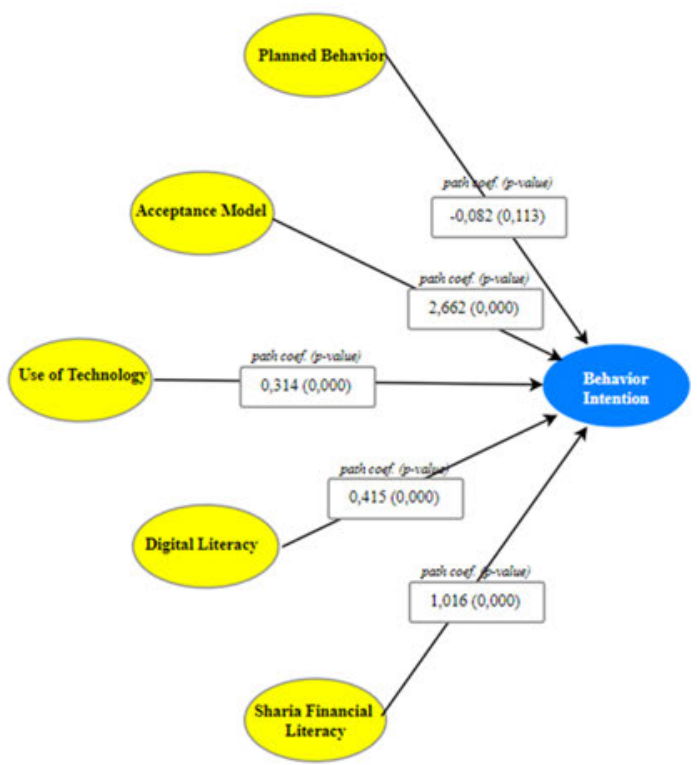


Table 5 The Direct relationship of the Structural Model of the Four Types of Sharia Fintech

\begin{tabular}{|c|c|c|c|c|c|c|}
\hline \multirow{3}{*}{$\begin{array}{l}\text { Types of Sharia } \\
\text { Fintech }\end{array}$} & \multirow{3}{*}{ Statistical Test } & \multicolumn{5}{|c|}{ Research Hypothesis } \\
\hline & & $\mathrm{H} 1$ & H2 & $\mathrm{H} 3$ & $\mathrm{H} 4$ & H5 \\
\hline & & $\mathrm{PB} \rightarrow \mathrm{BI}$ & $\mathrm{AM} \rightarrow \mathrm{BI}$ & $\mathrm{UT} \rightarrow \mathrm{BI}$ & $\mathrm{DL} \rightarrow \mathrm{BI}$ & $\mathrm{SFL} \rightarrow \mathrm{BI}$ \\
\hline \multirow{4}{*}{$\begin{array}{c}\text { Sharia Fintech: } \\
\text { Payment }\end{array}$} & $\begin{array}{c}\text { Path } \\
\text { Coefficient }\end{array}$ & 0.151 & 2.705 & 0.345 & 0.403 & 0.981 \\
\hline & t-statistics & 2.327 & 11.493 & 4.969 & 4.367 & 6.920 \\
\hline & $p$-values & 0.010 & 0.000 & 0.000 & 0.000 & 0.000 \\
\hline & Sig. & Significant & Significant & Significant & Significant & Significant \\
\hline \multirow{4}{*}{$\begin{array}{l}\text { Sharia Fintech: } \\
\text { Lending }\end{array}$} & $\begin{array}{c}\text { Path } \\
\text { Coefficient }\end{array}$ & 0.139 & 2.148 & 0.210 & 0.132 & 0.824 \\
\hline & t-statistics & 2.127 & 12.395 & 3.010 & 1.861 & 6.100 \\
\hline & $p$-values & 0.017 & 0.000 & 0.001 & 0.031 & 0.000 \\
\hline & Sig. & Significant & Significant & Significant & Significant & Significant \\
\hline \multirow{4}{*}{$\begin{array}{l}\text { Shariah Fintech: } \\
\text { Crowdfunding }\end{array}$} & $\begin{array}{c}\text { Path } \\
\text { Coefficient }\end{array}$ & 0.201 & 1.879 & 0.122 & 0.235 & 0.446 \\
\hline & t-statistics & 2.204 & 8.862 & 1.308 & 2.379 & 2.994 \\
\hline & $p$-values & 0.014 & 0.000 & 0.095 & 0.009 & 0.001 \\
\hline & Sig. & Significant & Significant & Insignificant & Significant & Significant \\
\hline \multirow{4}{*}{$\begin{array}{l}\text { Shariah Fintech: } \\
\text { Risk and } \\
\text { Management }\end{array}$} & $\begin{array}{c}\text { Path } \\
\text { Coefficient }\end{array}$ & -0.082 & 2.662 & 0.314 & 0.415 & 1.016 \\
\hline & t-statistics & 1.209 & 10.326 & 4.072 & 4.322 & 6.642 \\
\hline & $p$-values & 0.113 & 0.000 & 0.000 & 0.000 & 0.000 \\
\hline & Sig. & Insignificant & Significant & Significant & Significant & Significant \\
\hline
\end{tabular}

In a comparison of four types of sharia fintech (Figure 3), Darmansyah et al. (2020) found that the positive and significant influence of the (AM) on (BI) only occurred in the types of sharia fintech payments and fintech crowdfunding. Contrary, this study found that the (AM) and (BI) positive and significant influence occurred in all four types of sharia fintech explained before.

The positive and significant influence of the (UT) on (BI) occurs in sharia fintech payments, sharia fintech lending, fintech crowdfunding (donation-based), and sharia fintech risk and management. This result is contrary to the research of Darmansyah et al. (2020), which found that the positive and significant effect of (UT) on (BI) only occurred in the types of sharia fintech payments and sharia fintech lending. The analysis conducted on four types of sharia fintech shows that the influence of (DL) and (SFL) on (BI) occurs in sharia fintech payments, sharia fintech lending, fintech crowdfunding (donation-based), and fintech risk and sharia management. 


\section{Conclusion}

Muslims' behavior intentions in using sharia fintech have been proven to be explained by Planned Behavior, Acceptance Model, Use of Technology, Digital literacy, and Sharia Financial Literacy. All variables have a positive and significant relationship in influencing Muslim behavioral intentions in using Islamic finance. Acceptance Model, Digital literacy, Sharia Financial Literacy are crucial compared to Planned behavior and Use of Technology in influencing Muslim behavioral intentions using sharia fintech. All latent variables influence the use of sharia fintech in sharia payments and sharia lending in this study. However, in fintech crowdfunding, the Use of Technology variable does not show a significant effect. In Sharia fintech risk and management, the Planned behavior variable has no significant effect.

Develop the proper regulatory framework in the education curriculum so that the community can be digitally literate. It is expected that the government and policymakers will continue to improve infrastructure provision to support internet access equitably. Equitable infrastructure plays a vital role in increasing digital literacy. Likewise, sharia financial literacy (SFL) in this study is proven to have a strong influence in explaining the behavioral intentions of sharia fintech users.

\section{References}

Abhishek, \& Hemchand, S. (2016). Adoption of Sensor-Based Communication for Mobile Marketing in India. Journal of Indian Business Research, 8(1), 65-76. https://doi. org/10.1108/JIBR-08-2015-0091.

Affan, I. (2019). Analisis Faktor-Faktor Preferensi yang Mempengaruhi Keputusan Metode Pembayaran Zakat Bagi Muzakki di Era Digital (Studi pada Dosen dan Tenaga Kependidikan Fakultas Ekonomi dan Bisnis Universitas Brawijaya. Jurnal Ilmiah Mahasiswa Fakultas Ekonomi dan Bisnis, 8(1), 1-16.

Ajzen, I. (1985). From Intentions to Action: a Theory of Planned Behavior. Action Control, 2, 11-39. https://doi.org/10.1007/978-3-642-69746-3_2.

Akhtar, S., Irfan, M., Sarwar, A., Asma, \& Rashid, Q. U. A. (2019). Factors Influencing Individuals' Intention to Adopt Mobile Banking in China and Pakistan: The Moderating Role of Cultural Values". Journal of Public Affairs, 19(1), 1-15. https:// doi.org/10.1002/pa.1884.

Alalwan, A. A., Dwivedi, Y. K., \& Rana, N. (2017). Factors Influencing Adoption of Mobile Banking by Jordanian Bank Customers: Extending UTAUT2 with Trust. International Journal of Information Management, 33(3), 99-110. https://doi. org/10.1016/j.ijinfomgt.2017.01.002.

Apanasevic, T., Markendahl, J., \& Arvidsson, N. (2016). Stakeholders' Expectations of Mobile Payment in Retail: Lessons from Sweden. International Journal of Bank Marketing, 34(1), 37-61. https://doi.org/10.1108/IJBM-06-2014-0064. 
Baptista, G., \& Oliveira, T. (2015). Understanding Mobile Banking: The Unified Theory of Acceptance and Use of Technology Combined with Cultural Moderators. Computers in Human Behavior, 50, 418-430. https://doi.org/10.1016/j.chb.2015.04.024.

Belshaw, D. (2011). What is Digital Literacy? A Pragmatic Investigation. (Unpublished Ph.D Thesis). Durham: University of Durham, 274.

Coutinho, C. (2007). Cooperative Learning in Higher Education Using Weblogs: A Study with Undergraduate Students of Education in Portugal. IMSCI 2007 - International Multi-Conference on Society, Cybernetics and Informatics, Proceedings, 1, 60-64.

Darmansyah., Fianto, B. A., Hendratmi, A., \& Aziz, P. F. (2020). Factors Determining Behavioral Intentions to Use Islamic Financial Technology: Three Competing Models. Journal of Islamic Marketing, 12(4), 794-812. https://doi.org/10.1108/ JIMA-12-2019-0252.

Davis, F. D. (1989). Perceived Usefulness, Perceived Ease of Use, and User Acceptance of Information Technology. MIS Quarterly: Management Information Systems, 13(3), 319-339. https://doi.org/10.2307/249008.

Elhajjar, S., \& Ouaida, F. (2019). An Analysis of Factors Affecting Mobile Banking Adoption. International Journal of Bank Marketing, 38(2), 352-367. https://doi. org/10.1108/IJBM-02-2019-0055.

Ghozali, I., \& Latan, H. (2015). Partial Least Squares: Konsep, Teknik, dan Aplikasi Menggunakan Program Smart PLS 3.0 ( $2^{\text {nd }}$ ed.). Semarang: BP Undip.

Glavee-Geo, R., Shaikh, A. A., \& Karjaluoto, H. (2017). Mobile Banking Services Adoption in Pakistan: Are There Gender Differences? International Journal of Bank Marketing, 35(7), 1090-1114. https://doi.org/10.1108/IJBM-09-2015-0142.

Haider, M. J., Changchun, G., Akram, T., \& Hussain, S. T. (2016). Does Gender Difference Play Any Role in Intention to Adopt Islamic Mobile Banking? An Empirical Study. Journal of Islamic Marketing, 9(2), 439-460. https://doi. org/10.1108/JIMA-11-2016-0082.

Hargittai, E., \& Hinnant, A. (2008). Digital Inequality: Differences in Young Adults' Use of the Internet. Communication Research, 35(5), 602-621. https://doi.org/10.1177/ 0093650208321782 .

Hossain, A., Quaresma, R., \& Rahman, H. (2019). Investigating Factors Influencing the Physicians' Adoption of Electronic Health Record (EHR) in The Healthcare System of Bangladesh: An Empirical Study. International Journal of Information Management, 44, 76-87. https://doi.org/10.1016/j.ijinfomgt.2018.09.016.

Howard, P., Busch, L., \& Sheets, P. (2010). Comparing Digital Divides: Internet Access and Social Inequality in Canada and the United States. Canadian Journal of Communication, 35(1), 109-128.

Huei, C. T., Cheng, L. S., Seong, L. C., Khin, A. A., \& Leh Bin, R. L. (2018). Preliminary study on consumer attitude towards fintech products and services in Malaysia. 
International Journal of Engineering and Technology(UAE), 7(2), 166-169. https:// doi.org/10.14419/ijet.v7i2.29.13310.

Jeremy, J., Shapiro, K., S., \& Hughes. (1996). SK Information Literacy as a Liberal Art: Enlightenment Proposals for a New Curriculum. Educom Review, 31(2), 1-9.

Jung, L.-S. (2016). The Relationship Between Attitude and Satisfaction for Improving Continue User Intention in Fintech. International Journal of IT-Based Business Strategy Management, 2(1), 29-34.

Leong, L. Y., Hew, T. S., Tan, G. W. H., \& Ooi, K. B. (2013). Predicting the Determinants of the NFC-Enabled Mobile Credit card Acceptance: A Neural Networks Approach. Expert Systems with Applications, 40(14), 5604-5620. https:// doi.org/10.1016/ j.eswa.2013.04.018.

Mohd Thas Thaker, H., Khaliq, A., Ah Mand, A., Iqbal Hussain, H., Mohd Thas Thaker, M. A. B., \& Allah Pitchay, A. B. (2020). Exploring The Drivers of Social Media Marketing in Malaysian Islamic Banks: an Analysis via Smart PLS Approach. Journal of Islamic Marketing, 12(1), 145-165. https://doi.org/10.1108/JIMA-052019-0095.

Morgan, P. J., \& Long, T. Q. (2020). Financial Literacy, Financial Inclusion, and Savings Behavior in Laos. Journal of Asian Economics, 68(2), 101-197. https://doi. org/10.1016/ j.asieco.2020.101197.

Mukhtar, A. S., \& Ahmad, S. (2010). Transformasi Pengurusan Zakat di Malaysia. Proceeding the 4th ISDEV International Islamic Development Conference (IDMAC) Organized by the Centre for Islamic Development Management Studies (ISDEV), University of Science, Malaysia.

Narayan, P. K., \& Phan, D. H. B. (2019). A Survey of Islamic Banking and Finance Literature: Issues, Challenges, and Future Directions. Pacific-Basin Finance Journal, 53, 484-496. https://doi.org/10.1016/j.pacfin.2017.06.006.

Nedungadi, P., Devenport, K., Sutcliffe, R., \& Raman, R. (2020). Towards a Digital Learning Ecology to Address The Grand Challenge in Adult Literacy. Interactive Learning Environments, 1-14. https://doi.org/10.1080/10494820.2020.1789668.

Oliveira, T., Thomas, M., Baptista, G., \& Campos, F. (2016). Mobile Payment: Understanding The Determinants of Customer Adoption and Intention to Recommend The Technology. Computers in Human Behavior, 61(1), 404-414. https://doi.org/10.1016/j.chb.2016.03.030.

Ramos de Luna, I. R., Liébana-Cabanillas, F., Muñoz-Leiva, F., \& Sánchez-Fernández, J. (2019). The Adoption of Mobile Payment Systems Depending on The Technology Applied. Technological Forecasting \& Social Change, 146(9), 931-944. https://doi. org/10.1016/j.techfore.2018.09.018.

Rana, N. P., Dwivedi, Y. K., Williams, M. D., \& Weerakkody, V. (2015). Investigating Success of an E-Government Initiative: Validation of an Integrated IS Success Model. 
Information Systems Frontiers, 17(1), 127-142. https://doi.org/10.1007/s10796-0149504-7.

Raza, S. A., Shah, N., \& Ali, M. (2018). Acceptance of Mobile Banking in Islamic Banks: Evidence from Modified UTAUT Model. Journal of Islamic Marketing, 10(1), 357-376. https://doi.org/10.1108/JIMA-04-2017-

Rodríguez-de-Dios, I., Oosten, J. M., \& Igartua, J. J. (2018). A Study of The Relationship Between Parental Mediation and Adolescents' Digital Skills, Online Risks, and Online Opportunities. Computers in Human Behavior, 82, 186-198. https://doi. org/10.1016/ j.chb.2018.01.012.

Ryu, H. S. (2018). What Makes Users Willing or Hesitant to Use Fintech? The Moderating Effect of User Type. Industrial Management and Data Systems, 118(3), 541-569. https://doi.org/10.1108/IMDS-07-2017-0325

Schierz, P. G., Schilke, O., \& Wirtz, B. W. (2010). Understanding Consumer Acceptance of Mobile Payment Services: An Empirical Analysis. Electronic Commerce Research and Applications, 9(3), 209-216. https://doi.org/10.1016/j.elerap.2009.07.005.

Shin, D. H. (2009). Towards an Understanding of The Consumer Acceptance of Mobile Wallets. Computer in Human Behaviour, 25, 1343-1354. https://doi.org/10.1016/ j.chb.2009.06.001.

Slade, E. L., Dwivedi, Y. K., Piercy, N. C., \& Williams, M. D. (2015). Modeling Consumers' Adoption Intentions of Remote Mobile Payments in The United Kingdom: Extending UTAUT with Innovativeness, Risk, and Trust. Psychology \& Marketing, 32(8), 860-873. https://doi.org/10.1002/mar.20823.

Solomon, O., Shamsuddin, A., \& Wahab, E. (2013). Identifying Factors That Determine Intention to Use Electronic Banking: a Conceptual Study. Middle East Journal of Scientific Research, 18(07), 1010-1022.

Stewart, H., \& Jürjens, J. (2018). Data Security and Consumer Trust in FinTech Innovation in Germany", Information and Computer Security Emerald Insight. Information and Computer Security Emerald Insight, 26(1), 109-128. https://doi. org/10.1108/ICS-06-2017-0039.

Thaker, M. A. B. M. T., Pithcay, A. B. A., Thaker, H. B. M. T., \& Amin, Md. F. B. (2019). Factors Influencing Consumers 'Adoption of Islamic Mobile Banking Services in Malaysia. Journal of Islamic Marketing, 10(4), 1037-1056. https://doi. org/10.1108/JIMA-04-2018-0065.

Thakur, R., \& Srivastava, M. (2014). Adoption Readiness, Personal Innovativeness, Perceived Risk, and Usage Intention Across Customer Groups for Mobile Payment Services in India. Internet Research, 24(3), 369-392. https://doi.org/10.1108/IntR12-2012-0244.

Venkatesh, V., \& Davis, F. (2000). A Theoretical Extension of The Technology Acceptance Model: Four Longitudinal Field Studies. Management Science, 46(2), 186-204. 
Zhang, T., Lu, C., \& Kizildag, M. (2018). Banking "On-the-Go": Examining Consumers' Adoption of Mobile Banking Services. International Journal of Quality and Service Sciences, 10(3), 279-295. https://doi.org/10.1108/IJQSS-07-2017-0067. 